\title{
Peningkatan Keterampilan Menyimak Siswa Kelas V Sd Negeri 238 Palembang Melalui Model Paired Storytelling Dengan Menggunakan Media Audio Visual
}

\author{
Umar Effendy ${ }^{1}$, Asnimar ${ }^{2}$, Bunda Harini ${ }^{3}$, Nuraini Usman ${ }^{4}$, Dedy Hardiansyah ${ }^{5}$ \\ 1,2,3,4,5Program Studi Pendidikan Guru Sekolah Dasar Universitas Sriwijaya \\ 1'umar.effendy@ymail.com \\ 2as_sahupi@yahoo.com \\ 3harini.bunda@unsri.ac.id \\ 4aim_unsri@yahoo.com \\ ${ }^{5}$ dedyhardiansyah12@gmail.com
}

\begin{abstract}
ABSTRAK
Penelitian ini bertujuan meningkatkan keterampilan menyimak siswa kelas V SD Negeri 238 Palembang melalui model Paired Storytelling dengan menggunakan media audio visual. Metode yang digunakan dalam penelitian ini adalah kualitatif dalam bentuk penelitian tindakan. Subjek penelitian ini adalah seluruh siswa kelas Va SD Negeri 238 Palembang yang berjumlah 34. Penelitian ini bersifat kolaboratif, sehingga peneliti dan guru kelas tersebut dapat berkolaborasi. Pengumpulan data dilakukan dengan menggunakan tes hasil belajar dan tes kinerja keterampilan menyimak. Oleh karena itu, instrument penelitian ini adalah soal dan rubrik penilaian kinerja keterampilan menyimak. Penelitian tindakan ini dilakukan secara bersiklus yang tiap siklusnya terdiri atas empat tahap yaitu perencanaan, pelaksanaan tindakan, observasi, dan refleksi. Siklus dalam penelitian ini terdiri dari dua pertemuan. Berdasarkan data nilai rata-rata keterampilan menyimak, diketahui bahwa terjadi peningkatan dari 57.5 pada siklus I menjadi 74.5 pada siklus II. Oleh karena itu, penelitian ini berakhir pada siklus II. Berdasarkan hasil penelitian dan analisis data disimpulkan bahwa penerapan media audio visual dapat meningkatkan keterampilan menyimak siswa Kelas Va SD Negeri 238 Palembang melalui model Paired Storytelling.
\end{abstract}

Kata kunci: Keterampilan Menyimak, Model paired storytelling, Media audio visual

PENDAHULUAN
Bertitik tolak dari misi S 1 PGSD
FKIP Unsri yang berbasis KKNI
mengisyaratkan agar dosen/mahasiswa (1)
melaksanakan penelitian dan pengembangan
IPTEK yang berinovasi dalam
penyelenggaraan kependidikan Sekolah Dasar;
(2) melaksanakan pengabdian kepada
masyarakat dalam rangka menyebarluaskan
pengetahuan dan pembaharuan dalam bidang
pendidikan Sekolah Dasar; dan (3)
mengembangkan kerjasama dengan lembaga
lain yang berkontribusi terhadap
pengembangan pendidikan Sekolah Dasar.
PGSD FKIP Unsri salah satu LPTK,
di samping menghasilkan calon guru yang
profesonal memiliki tanggung jawab besar
dalam membina guru-guru SD di
lingkungannya. Menghadapi pemberlakuan
Kurikulum 2013 secara nasional tahun 2018
yang berbasis terpadu dengan pendekatan
Saintifik, guru-guru harus menyiapkan diri
dengan baik. Di samping memahami dengan
baik pendekatan Saintifik yang melandasinya,

guru-guru harus disiapkan dengan berbagai model pembelajaran yang baik.

Sekolah Dasar merupakan lembaga pendidikan dasar untuk anak. Di Sekolah Dasar anak-anak mulai mengembangkan kemampuan dan potensi yang mereka miliki. Ada berbagai macam mata pelajaran yang diajarkan pada jenjang Sekolah Dasar. Salah satunya mata pelajaran bahasa Indonesia. Pembelajaran Bahasa Indonesia tidak terlepas dari interaksi manusia. Agar interaksi itu berjalan dengan baik maka diperlukan suatu alat komunikasi. Alat komunikasi yang utama bagi manusia adalah bahasa. Agar komunikasi berjalan dengan baik, diperlukan penguasaan keterampilan berbahasa. Keterampilan berbahasa memiliki empat aspek, yaitu: 1) keterampilan menyimak, 2) keterampilan berbicara, 3) keterampilan membaca, dan 4) keterampilan menulis. (Tarigan 2008:2).

Untuk meningkatkan kemampuan berbahasa tersebut salah satunya adalah dengan cara meningkatkan keterampilan menyimak siswa. Memiliki kemampuan 
menyimak yang baik sangat penting dimiliki oleh setiap siswa, karena dengan kemampuan menyimak yang baik akan mempermudah siswa dalam menguasai dan memahami mata pelajaran lainnya. Sejalan dengan hal tersebut Saddhono (2014:17) mengatakan "keterampilan menyimak merupakan aktivitas atau kegiatan yang paling awal dilakukan oleh anak manusia bila dilihat dari proses pemerolehan keterampilan bahasa".

Aktivitas menyimak menduduki porsi terbesar dari waktu keseharian hidup manusia. Menurut Bird hasil penelitiannya bahwa seorang mahasiswa pada perguruan tinggi dalam perkuliahan membagi aktivitasnya sebagai berikut: menyimak $42 \%$, berbicara $25 \%$, membaca $15 \%$, dan menulis $18 \%$ (dikutip Saddhono 2014:19). Seiring dengan yang yang dikemukakan oleh Rankin bahwa pada umumnya seseorang menggunakan $45 \%$ waktunya untuk menyimak, $30 \%$ untuk berbicara, 16\% untuk membaca, dan hanya $9 \%$ saja untuk menulis (dikutip Tarigan 2008:139). Berdasarkan hasil penelitian di atas, sudah terlihat jelas keberhasilan seorang siswa itu diawali dengan bagaimana pemerolehan keterampilan menyimak siswa.

Model Paired Story Telling merupakan model pembelajaran yang tepat digunakan untuk pembelajaran menyimak. Model pembelajaran Paired Story Telling menggabungkan kegiatan membaca, menulis, mendengarkan, dan berbicara. Pada prinsipnya, model pembelajaran Paired Story Telling merupakan model pembelajaran interaktif, karena menekankan pada keterlibatan aktif siswa selama proses pembelajaran. Dalam kegiatan ini, siswa dirangsang untuk mengembangkan kemampuan berpikir dan berimajinasi. Hasil pemikiran siswa akan dihargai sehingga siswa akan terdorong untuk terus belajar (Huda, 2013:151-153).

Selain menggunakan model, penggunaan media audio visual dalam pembelajaran menyimak diharapkan meningkatkan rasa ingin tahu dan minat siswa serta memotivasi belajar. Jika siswa termotivasi, maka siswa akan mengikuti pembelajaran dengan sebaik dan semaksimal mungkin. Dengan demikian, diharapkan akan mampu meningkatkan keterampilan menyimak pada siswa yang dapat diidentifikasi dari hasil belajar siswa dan berubahnya sikap siswa ke arah positif.

Setelah melakukan observasi pada siswa kelas V di beberapa SD mitra PGSD FKIP Unsri Palembang yang dilakukan oleh tim peneliti, diperoleh fakta bahwa kemampuan menyimak pada siswa masih kurang maksimal. Peneliti mengadakan evaluasi dengan memberikan cerita, siswa diminta untuk menyimak cerita yang disampaikan oleh peneliti. Kemudian peneliti meminta siswa untuk menyampaikan kembali isi teks bacaan yang disimak dengan bahasa yang runtut, baik, dan benar. Terbukti bahwa isi teks yang disampaikan oleh siswa tersebut kurang sesuai dengan isi teks yang dibacakan oleh tim peneliti.

Melihat fakta yang ada di lapangan yang dilihat oleh tim peneliti pada siswa kelas V SD mitra Palembang ini, peneliti menemukan beberapa permasalahan dalam pelaksanaan kegiatan menyimak, yaitu kurang keterbiasaan siswa untuk menyimak dan bahkan ada hampir semua siswa yang mengabaikan mata pelajaran bahasa Indonesia. Selain itu juga anak cepat merasa tidak tertarik untuk belajar bahasa Indonesia, karena selama ini dalam pembelajaran siswa hanya disodorkan materi pembelajaran dengan metode ceramah dan kurang variasi guru dalam menerapkan model yang efektif. Sehingga, anak kurang tertarik dan cepat merasa bosan.

Berdasarkan latar belakang di atas, rumusan masalah dalam penelitian ini adalah apakah dengan menggunakan media audio visual melalui model Paired Story Telling (PST) dapat meningkatkan kemampuan menyimak siswa kelas V SD Negeri 238 Palembang. Sesuai dengan permasalahan, maka tujuan yang dicapai dalam penelitian ini adalah untuk mendeskripsikan hasil dan proses pembelajaran media audio visual melalui model Paired Storytelling dalam upaya meningkatkan kemampuan menyimak siswa kelas V SD Negeri 238 Palembang.

\section{METODE PENELITIAN}

Penelitian ini diarahkan pada penelitian tindakan kelas yang bersifat kolaboratif. Artinya, guru dan peneliti dapat melakukan kolaborasi. Metode yang digunakan adalah kualitatif dalam bentuk penelitian tindakan. Selanjutnya, dilakukan tindakan dalam suatu siklus untuk mengetahui peningkatan keterampilan menyimak siswa kelas V Sekolah Dasar.

Subjek penelitian ini adalah seluruh siswa kelas Va SD Negeri 238 Palembang. Jumlah siswa adalah 34 dengan rincian 16 siswa putri dan 18 siswa putra. SD Negeri 238 Palembang beralamatkan di jalan srijaya KM 
5.5 Kelurahan Srijaya, Kecamatan Alang-alang Lebar, Kota Palembang. Sekolah tersebut juga memiliki letak yang berseberangan dengan Kampus PGSD FKIP Universitas Sriwijaya, sekaligus menjadi mitra PGSD FKIP Universitas Sriwijaya.

Instrumen yang akan digunakan dalam penelitian ini antara lain lembar pedoman observasi dan soal tes hasil belajar. Lembar observasi digunakan untuk mengukur keterampilan menyimak siswa. Soal tes hasil belajar digunakan untuk mengukur hasil belajar ranah kognitif, sedangkan tes keterampilan menyimak sebagai hasil belajar ranah psikomotor. Selain itu, ranah afektif juga menjadi perhatian dalam penelitian ini. Sehingga, ketiga ranah dalam pembelajaran menjadi terpenuhi.

Indikator keberhasilan dalam penelitian ini adalah hasil observasi keterampilan menyimak sebagai penilaian ranah psikomotor, soal tes hasil belajar sebagai penilaian ranah kognitif, dan observasi aktivitas siswa di kelas sebagai ranah afektif. Jika pada siklus pertama menunjukan klasikal keterampilan menyimak dan hasil belajar siswa sudah dapat meningkat secara signifikan pada setiap pertemuan, maka siklus kedua tidak perlu dilaksanakan. Namun jika siklus pertama belum mencapai kriteria minimal keterampilan guru membuat media pembelajaran berbasis komputer, maka perlu diadakan siklus kedua begitu juga seterusnya.

\section{HASIL \& PEMBAHASAN}

Penelitian ini dilakukan pada siswa kelas SD Negeri 238 Palembang. Penelitian berlangsung selama \pm 2 bulan terhitung dari bulan September hingga bulan Oktober minggu keempat mulai dari tahap persiapan, pelaksanaan dan penulisan laporan penelitian. Penelitian tindakan ini dilaksanakan dalam 2 kali siklus yang sudah dianggap mampu memenuhi kepuasan peneliti dalam mencapai hasil yang diinginkan dan mengatasi persoalan yang ada. Setiap siklus terdiri dari 4 tahapan, yaitu perencanaan, pelaksanaan, pengamatan, dan refleksi. Selanjutnya, setiap siklus terdiri dari 2 pertemuan. Hasil penelitian ini merupakan pendeskripsian data hasil tindakan siklus pertama dan kedua.

Pelaksanaan penelitian pada siklus I telah dilakukan selama dua kali tindakan. Dalam siklus I dapat diuraikan beberapa hal mengenai kegiatan perencanaan, pelaksanaan, pengamatan, dan refleksi. Pada tahapan perencanaan diawali dengan mendiskusikan langkah-langkah tindakan yang dilakukan di siklus I. Kegiatan perencanaan dilakukan pada minggu kedua bulan September. Perencanaan tersebut dilakukan sebagai acuan dalam melaksanakan tindakan pada siklus I. Selain itu, direncanakan juga bentuk evaluasi untuk siklus I. Sehingga, format evaluasi dan lembar pedoman observasi telah dirancang pada tahap perencanaan siklus I. Tahap tindakan dilakukan sebanyak dua kali. Hal tersebut mengingat keterbatasan penelitian ini. Tindakan pertama ditayangkan video yang berisi cerita Lutung Kasarung, sedangkan tindakan kedua ditayangkan video Reog Ponorogo.

Tindakan pertama pada siklus I dilaksanakan pada minggu ketiga bulan September. Siswa kelas Va SD Negeri 238 Palembang diberikan tindakan pada tanggal 22 September 2017 pada pukul $08.00-09.30$ WIB. Siswa kelas Va SD Negeri 238 Palembang mengamati video Lutung Kasarung. Cerita Lutung Kasarung berasal dari Sunda yang merupakan suku di Jawa Barat. Pengamatan video yang dilakukan siswa telah dilibatkan dengan model PST. Oleh karena itu, siswa dibentuk dalam kelompok yang berpasang-pasangan. Kegiatan pendahuluan dalam tindakan dilakukan oleh guru, selanjutnya peneliti melaksanakan kegiatan inti, kegiatan penutup dilakukan kembali oleh guru.

Tindakan kedua pada siklus I dilaksanakan pada minggu keempat bulan September. Siswa kelas Va SD Negeri 238 Palembang diberikan tindakan pada tanggal 29 September 2017 pada pukul $08.00-09.30$ WIB. Siswa kelas Va SD Negeri 238 Palembang mengamati video Ande-ande Lumut. Cerita Ande-ande Lumut berasal dari Jawa yang juga merupakan suku di Pulau Jawa. Pengamatan video yang dilakukan siswa telah dilibatkan dengan model PST. Oleh karena itu, siswa dibentuk dalam kelompok yang berpasang-pasangan. Kegiatan pendahuluan dalam tindakan dilakukan oleh guru, selanjutnya peneliti melaksanakan kegiatan inti, kegiatan penutup dilakukan kembali oleh guru.

Pelaksanaan penelitian pada siklus II juga telah dilakukan selama dua kali tindakan. Dalam siklus II dapat diuraikan beberapa hal mengenai kegiatan perencanaan, pelaksanaan, pengamatan, dan refleksi. Pada tahapan perencanaan diawali dengan mendiskusikan langkah-langkah tindakan yang dilakukan di siklus II. Kegiatan perencanaa dilakukan pada minggu pertama bulan Oktober. Perencanaan tersebut dilakukan sebagai acuan dalam 
melaksanakan tindakan pada siklus II. Selain itu, direncanakan juga bentuk evaluasi untuk siklus II. Sehingga, format evaluasi dan lembar pedoman observasi telah dirancang pada tahap perencanaan siklus II. Tahap tindakan dilakukan sebanyak dua kali. Hal tersebut mengingat keterbatasan penelitian ini. Tindakan pertama ditayangkan video yang berisi cerita Roro Jonggrang, sedangkan tindakan kedua ditayangkan video Cindelaras.

Tindakan pertama pada siklus II dilaksanakan pada minggu kedua bulan Oktober. Siswa kelas Va dan Vb SD Negeri 238 Palembang diberikan tindakan pada tanggal 13 Oktober 2017 pada pukul 08.00 09.30 WIB. Siswa kelas Va SD Negeri 238 Palembang mengamati video Roro Jonggrang. Cerita Roro Jonggrang berasal dari Daerah Istimewa Jogjakarta. Pengamatan video yang dilakukan siswa telah dilibatkan dengan model PST. Oleh karena itu, siswa dibentuk dalam kelompok yang berpasang-pasangan. Kegiatan pendahuluan dalam tindakan dilakukan oleh guru, selanjutnya peneliti melaksanakan kegiatan inti, kegiatan penutup dilakukan kembali oleh guru.

Tindakan kedua pada siklus II dilaksanakan pada minggu ketiga bulan Oktober. Siswa kelas Va dan Vb SD Negeri 238 Palembang diberikan tindakan pada tanggal 20 Oktober 2017 pada pukul 08.00 09.30 WIB. Siswa kelas Va SD Negeri 238 Palembang mengamati video Cindelaras. Cerita Cindelaras berasal dari Provinsi Jawa Timur. Pengamatan video yang dilakukan siswa telah dilibatkan dengan model PST. Oleh karena itu, siswa dibentuk dalam kelompok yang berpasang-pasangan. Kegiatan pendahuluan dalam tindakan dilakukan oleh guru, selanjutnya peneliti melaksanakan kegiatan inti, kegiatan penutup dilakukan kembali oleh guru.

Tahapan pengamatan dilaksanakan secara langsung bersamaan dengan pelaksanaan tindakan. Pengamatan dilakukan oleh peneliti secara bersama-sama dengan menggunakan lembar pedoman pengamatan yang telah dibuat pada tahap perencanaan. Aspek yang diamati terdiri dari kelengkapan informasi kata kunci, kesesuaian isi cerita, dan susunan kalimat. Masing-masing aspek memiliki 4 deskriptor yang menggambarkan aspek tersebut.

Deskriptor aspek kelengkapan informasi kata kunci, yaitu: (1) menuliskan beberapa kata kunci sesuai dengan alur tayangan; (2) banyaknya kata kunci sesuai dengan bahan simakan; (3) menggunakan kata yang lugas; dan (4) kata kunci sesuai dengan isi tayangan. Deskriptor aspek kesesuaian isi cerita, yaitu: (1) mengarang cerita berdasarkan kata kunci; (2) cerita disajikan secara runtut; (3) cerita hasil karangan sesuai dengan alur tayangan; dan (4) mengarang dengan bahasa yang baik dan benar. Deskriptor aspek susunan kalimat, yaitu: (1) kalimat tersusun sesuai alur tayangan; (2) menggunakan tanda baca sesuai dengan kebutuhan; (3) menggunakan kalimat efektif yang mudah dipahami; dan (4) penggunaan kaidah EYD yang baik dan benar. Nilai siswa dikategorikan menjadi amat baik, baik, cukup, dan kurang.

Hasil pengamatan atas keterampilan menyimak siswa pada siklus I dan II berdasarkan aspek-aspek tersebut beserta masing-masing deskriptor dapat dilihat pada tabel sebagai berikut.

Tabel 1 Nilai Rata-rata Kelas Keterampilan Menyimak

\begin{tabular}{ccccc}
\hline No & Siklus & Pertemuan I & Pertemuan II & Rata-rata \\
\hline 1 & I & 60 & 55 & 57.5 \\
2 & II & 71 & 78 & 74.5 \\
\hline
\end{tabular}

Berdasarkan tabel 1 terlihat bahwa nilai ratarata kelas pada siklus I untuk pertemuan pertama adalah 60, sedangkan pertemuan kedua adalah 55. Sehingga, diperoleh nilai rata-rata untuk siklus I adalah 57.5. Nilai ratarata kelas pada siklus II untuk pertemuan pertama adalah 71, sedangkan pertemuan kedua adalah 78. Sehingga, diperoleh nilai rata-rata untuk siklus II adalah 74.5.
Pengamatan tidak hanya dilakukan pada ranah psikomotor, dalam hal ini keterampilan menyimak siswa. Akan tetapi, kedua ranah lainnya juga diamati. Kedua ranah tersebut adalah kognitif dan psikomotor. Ketiga ranah tersebut dapat dilihat pada tabel nilai hasil belajar sebagai berikut. 
Tabel 2 Nilai Rata-rata Kelas Hasil Belajar

\begin{tabular}{lccccc}
\hline No & Siklus & \multicolumn{3}{c}{ Ranah } & Nilai \\
\cline { 3 - 5 } & & Afektif & Kognitif & Psikomotor & Rata-rata \\
$\mathbf{1}$ & I & 75.88 & 55.79 & 57.5 & 63.76 \\
$\mathbf{2}$ & II & 77.73 & 80.62 & 74.5 & 77.41 \\
\hline
\end{tabular}

Berdasarkan tabel 2 terlihat bahwa pada siklus I dan II terdapat perubahan nilai rata-rata hasil belajar. Nilai rata-rata pada siklus I untuk ranah afektif sebesar 75.88, ranah kognitif sebesar 55.79, ranah psikomotor sebesar 57.5. Sehingga, diperoleh nilai ratarata pada siklus I sebesar 63.76. Nilai rata-rata pada siklus II untuk ranah afektif sebesar 77.73, ranah kognitif sebesar 80.62, ranah psikomotor sebesar 74.5. sehingga, diperoleh nilai rata-rata pada siklus II sebesar 77.41.

Data tersebut menunjukan bahwa penerapan media audio visual dapat meningkatkan keterampilan menyimak melalui model paired storytelling bagi siswa kelas Va SD Negeri 238 Palembang. Hal ini sejaran dengan pendapat Lie (dikutip Hutabarat 2011:7) menyatakan bahwa model paired storytelling dapat diterapkan juga dalam pembelajaran keterampilan menyimak. Hermawan dkk (2016) dalam penelitiannya juga mengemukakan bahwa model paired storytelling juga dapat meningkatkan keterampilan berbahasa.

eningkatan yang telah terjadi pada penelitian ini sesuai dengan pendapat Huda (2011) yang menyatakan bahwa model ini dapat diterapkan dalam pembelajaran membaca, menulis, mendengarkan ataupun berbicara. Disamping itu, penelitian ini sejalan dengan penelitian yang telah dilakukan Eva Rosdiana pada tahun 2013 yang berjudul "Pengaruh Model Pembelajaran Kooperatif Tipe Paired Storytelling Berbantuan Media Audio Visual Terhadap Keterampilan Menyimak Bahasa Indonesia Kelas V SD”. Hasil penelitian yang telah dilakukan menyatakan bahwa model pembelajaran kooperatif tipe paired storytelling mempengaruhi keterampilan menyimak siswa. Kelas eksperimen yang menggunakan model pembelajaran kooperatif tipe paired storytelling mendapat skor post-test sebesar 7,14 sedangkan kelas kontrol yang menggunakan pembelajaran konvensional mendapat hasil post-test sebesar 6,26.

Selain itu, penelitian yang dilakukan oleh Afianti Rahmawati pada tahun 2013 dengan skripsi yang berjudul "Peningkatan Keterampilan Menyimak Dongeng Melalui Model Paired Storytelling Dengan Media Wayang Kartun Pada Siswa Kelas II SDN
Mangunsari Semarang” juga sejalan dengan penelitian ini. Hasil penelitian yang telah dilakukan menyatakan bahwa penerapan model paired storytelling dapat meningkatkan ketuntasan belajar siswa. Hal ini dapat dilihat dari perbedaan saat prasiklus ketuntasan belajar siswa hanya $40,9 \%$, setelah dilakukan penelitian sampai pada siklus II ketuntasan belajar siswa mencapai 90,9\%.

\section{KESIMPULAN \& SARAN}

Berdasarkan hasil penelitian dan analisis data dapat ditarik kesimpulan bahwa penerapan media audio visual telah dapat meningkatkan keterampilan menyimak siswa kelas V SD melalui Model PST. Hal itu terlihat dari diagram dan tabel yang telah disajikan pada hasil penelitian. Siswa sudah pernah menggunakan media dalam pembelajaran, namun media audio visual belum digunakan. Hal itu dikarenakan fasilitas yang dimiliki sekolah belum memadai. Selanjutnya, model pembelajaran juga sudah beberapa kali digunakan guru kelas V. Namun, model PST belum pernah digunakan, terutama dalam pembelajaran keterampilan menyimak.

Pada siklus I, penggunaan model PST melalui media audio visual belum terlihat efektif. Hal itu ditunjukan dari masih ada nilai yang belum mengalami peningkatan. Perubahan nilai yang terjadi pada siklus I belum mengarah pada peningkatan. Setelah guru dan peneliti melakukan refleksi atas hal yang terjadi pada siklus I, barulah perubahan peningkatan terjadi pada siklus II. Oleh karena itu, penelitian tindakan kelas ini diakhir pada siklus II.

Berdasarkan hasil penelitian dan kesimpulan, peneliti perlu menyampaikan saran-saran sebagai berikut.

1) Bagi sekolah untuk menambah dan mengembangkan sarana dan prasarana demi tercapainya pelaksanaan Model PST melalui model audio visual.

2) Bagi guru agar meningkatkan dan mengembangkan kemampuan, sehingga secara kontiniu dapat menggunakan Model PST dalam pembelajaran.

3) Bagi siswa, dengan model PST agar terus meningkatkan keterampilan menyimak 
sehingga lebih aktif lagi dalam proses pembelajaran.

\section{DAFTAR PUSTAKA}

Arikunto, Suharsimi, dkk. 2012. Penelitian Tindakan Kelas.Jakarta:Bumi Aksara.

Arsyad, Azhar. 2012. Media Pembelajaran. Bandung:Pustaka Indonesia.

Aunurrahman. 2009. Belajar dan Pembelajaran. Bandung:Alfabeta.

Aqib, Zainal dkk. 2010. Penelitian Tindakan Kelas. Bandung: Yrama Widya.

Depdiknas. 2006. Kurikulum Tingkat Satuan Pendidikan (KTSP). Jakarta: Departemen Pendidikan Nasional.

Fransiska, Carolina. 2013. Peningkatan Kemampuan Menyimak Isi Cerita dengan Menggunakan Media Audio Storytelling Terekam di Kelas V SDN 3 Panarung Palangka Raya. JURNAL PENDIDIKAN HUMANIORA, HAL 289-297 Volume 1, Nomor 3, September 2013

Hamdani. 2011. Strategi Belajar Mengajar. Bandung: Pustaka Setia.

Hermawan dkk. 2016. Penerapan Model Pembelajaran Paired Storytelling untuk Meningkatkan Keterampilan Berbicara pada Mata Pelajaran Bahasa Indonesia. e-Journal PGSD Universitas Pendidikan Ganesha Jurusan PGSD Vol: 4 No: 1 Tahun: 2016.

Huda, Miftahul. 2013. Cooperative Learning. Yogyakarta: Pustaka Pelajar.

Hutabara, Diana. 2011. Upaya Meningkatkan Keterampilan Berbicara Siswa Kelas IV SD Negeri 133 Palembang Melalui Teknik Pembelajaran Paired Story Telling. Skripsi. Palembang: FKIP Universitas Sriwijaya.

Liana, Ade. 2013. Penggunaan Media Audio Visual Film untuk Meningkatkan Keterampilan Menyimak dan Berbicara.Universitas Pendidikan Indonesia.

Mulyasa, H.E. 2013. Praktik Penelitian Tindakan Kelas. Bandung: Remaja Rosdakarya.

Puspita, D.M. 2012. Penggunaan media video untuk meningkatkan kemampuan menyimak cerita pada siswa kelas V SDN Sekarpuro Kabupaten Malang. Skripsi S1 Program Studi PGSD. Malang: Universitas Negeri Malang.

Rahayu, Istihanah. 2013. Peningkatan Keterampilan Menyimak Cerita Menggunakan Media Audio Visual Kelas
$V$ SD. JPGSD Volume 01 Nomor 02 Tahun 2013, 0-216

Saddhono,Kundharu. 2014. Pembelajaran Keterampilan Berbahasa Indonesia. Yogyakarta:Graha Ilmu.

Tarigan, Hendry Guntur. 2008. Keterampilan Menyimak. Jakarta: Angkasa Bandung. 